\title{
Influence of under pressure dissolved oxygen on trichloroethylene degradation by the $\mathrm{H}_{2} \mathrm{O}_{2} / \mathrm{TiO}_{2}$ process
}

\author{
Mohammad Hoseini ${ }^{1}$, Ramin Nabizadeh ${ }^{1,2^{*}}$, Shahrokh Nazmara ${ }^{1}$ and Gholam Hossein Safari ${ }^{1}$
}

\begin{abstract}
Background: The widespread use of trichloroethylene (TCE) and its frequent release into the environment has caused many environmental and health problems. In this study the degradation of TCE at different micromolar concentrations was investigated in a stainless steel reactor with various concentrations of $\mathrm{H}_{2} \mathrm{O}_{2}$ and $\mathrm{TiO}_{2}$ at different oxygen pressures and three different pHs.

Methods: To examine the synergistic effect of under pressure oxygen on TCE degradation, the concentrations of $\mathrm{H}_{2} \mathrm{O}_{2}$ and $\mathrm{TiO}_{2}$ as well as $\mathrm{pH}$ were first optimized, and then the experiments were performed under optimal conditions. Gas chromatography with a flame ionization detector (FID) was used to measure TCE concentrations.

Results: Results showed that the percentage of TCE degradation without pressurized oxygen was low and it increased with increasing pressure of oxygen at all initial concentrations of TCE. The degradation percentages without oxygen pressure were 48.27\%, 51.22\%, 58.13\% and 64.33\% for TCE concentrations of 3000, 1500, 300 and $150 \mathrm{\mu g} / \mathrm{L}$ respectively. At an oxygen pressure of 2.5 atmospheres (atm) the percent degradation of TCE reached 84.85\%, 89.14\%, 93.13\% and 94.99\% respectively for the aforementioned TCE concentrations.

Conclusions: The results of this study show that the application of dissolved oxygen under pressure increases the efficiency of the $\mathrm{H}_{2} \mathrm{O}_{2} / \mathrm{TiO}_{2}$ process on the degradation of TCE and can be used along with other oxidants as an effective method for the removal of this compound from aqueous solutions.
\end{abstract}

\section{Background}

TCE is described by the US Environmental Protection Agency (EPA) as a halogenated aliphatic organic compound which has been widely used as an industrial solvent in applications including dry cleaning, paint stripping and chemical, pharmaceutical, and plastic manufacturing. It is used mainly as a degreasing agent because of its unique properties and solvent effects [1,2].

It is estimated that the production of TCE in 1990 was approximately 131 kilotons in Western Europe, 79 kilotons in the United States of America and 57 kilotons in Japan and its annual consumption in these areas was estimated as $65-103 \%$ of production levels [3]. Due to its widespread use and physical characteristics, TCE may enter into water

\footnotetext{
* Correspondence: rnabizadeh@tums.ac.ir

'Department of Environmental Health Engineering, School of Public Health, Tehran University of Medical Sciences, Poursina St, Tehran, Iran

${ }^{2}$ Center for Air Pollution Research, Institute for Environmental Research,

Tehran University of Medical Sciences, Krgar St, Tehran, Iran
}

supplies and groundwater. Drinking water supplies that use groundwater sources contaminated with TCE may contain this compound [1]. According to reports from the Agency for Toxic Substances and Disease Registry (ATSDR) TCE is the most frequently reported organic contaminant in groundwater in the US. The TCE-contaminated drinking water supply sources in the US are estimated at between $9-34 \%$ of total water supply sources $[1,4]$.

It has been reported that exposure to TCE has many adverse effects on human health. Most of the reported effects have been associated with the effects of TCE on the central nervous system, with reported symptoms of fatigue, sleepiness, headache, confusion, and blurred vision $[1,4]$. Other effects on the liver, kidneys, gastrointestinal tract, and skin have also been reported [5]. According to US.EPA reports, exposure to TCE is associated with cancer of the kidneys and other organs [1]. It was also reported that TCE can cause loss of hearing in laboratory animals [4]. This compound induces cancer 
in mice and rats and it is considered as a probable carcinogenic chemical (Group $B_{2}$ ) to humans [6].

Conventional water and wastewater treatment processes such as coagulation, sedimentation, precipitative softening, filtration and chlorination have failed to reduce concentrations of TCE to nonhazardous levels [7]. Treatment technologies such as adsorption by activated carbon and air stripping are effective in removing TCE from contaminated waters. Nakano et al. however, believe that transformation of TCE from one phase to another phase would be the most disadvantageous of these processes [8].

During the past several years numerous studies have been performed to investigate various techniques and technologies for the removal of this pollutant from contaminated water. Amongst different kinds of degradation and removal methods, advanced oxidation processes (AOPs) provide an effective means of rapidly treating this pollutant with efficient process control $[7,9]$. There are some reports regarding TCE degradation by various advanced oxidation processes such as $\mathrm{H}_{2} \mathrm{O}_{2}$ /iron (II) (Fenton's reaction) [9], ultrasound $/ \mathrm{H}_{2} \mathrm{O}_{2}$ [10], gammarays $/ \mathrm{O}_{3}$ and $\mathrm{H}_{2} \mathrm{O}_{2}$ /gamma-rays [11]. Cross et al. investigated the effects of the direct addition of dissolved oxygen on the combination of copper ions and ascorbic acid in an oxidation process known as a modified Fenton reagent. They reported that dissolved oxygen has a considerable synergistic effect on this system's efficiency [12]. The main objective of this work was to investigate the synergetic effect of under pressure dissolved oxygen (UPDO) on TCE degradation by $\mathrm{H}_{2} \mathrm{O}_{2}$ and $\mathrm{TiO}_{2}$ nanoparticles. The effects of different operating conditions such as $\mathrm{TiO}_{2}$ and $\mathrm{H}_{2} \mathrm{O}_{2}$ concentration, $\mathrm{pH}$, and oxygen pressure on TCE removal efficiency were explored.

\section{Materials and methods}

\section{General procedures}

This experimental study was conducted in bench scale and batch system on synthetic solutions containing different concentrations of TCE. Aqueous solutions with different initial concentrations of TCE $(150,300,1500$, and $3000 \mu \mathrm{g} / \mathrm{L}$ ) were prepared by dissolving TCE (Merck Co., Germany- Cat. No. 100958) in distilled and deionized (DD) water. The selection of these concentrations was based on TCE levels found in underground water in Tehran which ranged from 97.7 to $1345.7 \mu \mathrm{g} / \mathrm{L}$ [13]. $\mathrm{TiO}_{2}$ particles (P25, Degussa AG, Germany) with a primary particle diameter of $21 \mathrm{~nm}$, specific surface area of $50 \pm 15$ $\mathrm{m}^{2} / \mathrm{g}$, and a crystal distribution of $80 \%$ anatase and $20 \% \mathrm{ru}-$ tile were used as the catalyst for the experiments and dosed in the range of $25-200 \mathrm{mg} / \mathrm{L}$. Four different concentrations $(10,25,50$, and $100 \mathrm{mg} / \mathrm{L})$ of $\mathrm{H}_{2} \mathrm{O}_{2}$ were made by dissolving $30 \% \mathrm{H}_{2} \mathrm{O}_{2}$ (Merck Co., Germany- Cat. No. 108597) in samples and concentrations were validated by iodometric back titration with $0.1 \mathrm{~N}$ sodium thiosulfate [9]. For adjustments of $\mathrm{pH}, \mathrm{NaOH}$ and $\mathrm{HCl}$ supplied from Merck Co. were used and the $\mathrm{pH}$ values were measured using a $\mathrm{pH}$ meter (Metrohm E520). The prepared TCE solutions along with the given concentrations of $\mathrm{TiO}_{2}$ and $\mathrm{H}_{2} \mathrm{O}_{2}$ were exposed to different oxygen pressures $(1,1.5,2$, and $2.5 \mathrm{~atm})$ at different reaction times of $15,30,45,60,90$, and $120 \mathrm{mi}-$ nutes. For each run, the experiments were conducted three times and the averages were reported.

\section{Pilot set-up}

All experiments were performed in a $6 \mathrm{~L}$ stainless steel reactor which was connected by a plastic pipe to a cylinder containing $99.9 \%$ pure oxygen (Figure 1). After the addition of $2 \mathrm{~L}$ of prepared solution to the reactor and

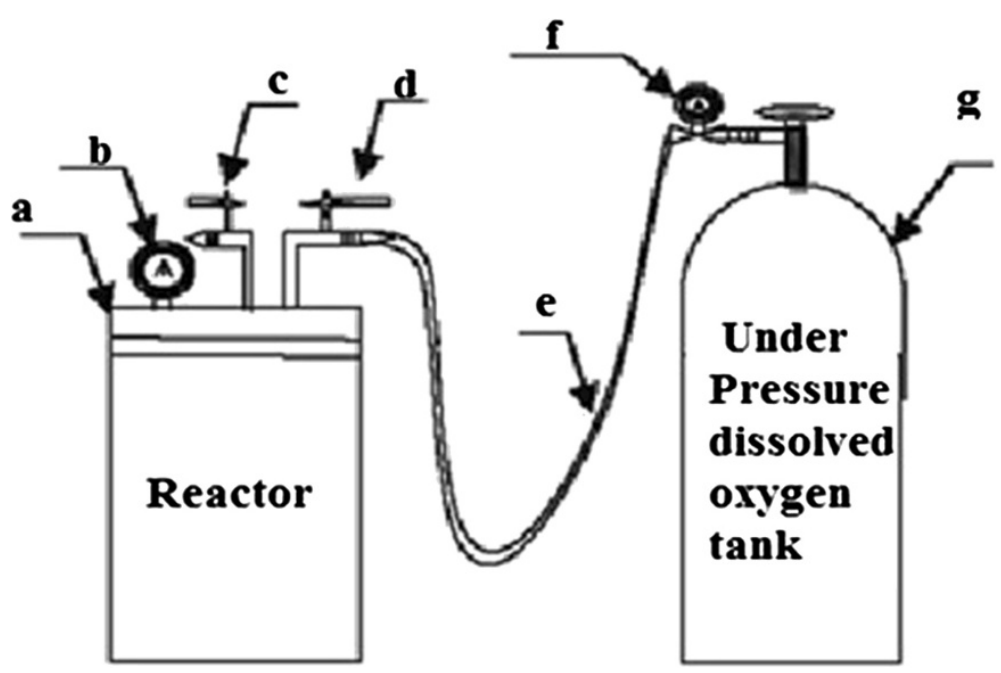

Figure 1 Schematic representation of the pilot set-up: a- Screw cap, b- Pressure gauge, c- Ball valve for gas pressure regulation, $d$ - Ball valve for oxygen gas entrance, e- Connector hose, $f$ - Pressure reducing Valve, g- Oxygen cylinder. 
the application of appropriate doses of $\mathrm{H}_{2} \mathrm{O}_{2}$ and/or $\mathrm{TiO}_{2}$ nano-particles, the reactor was completely sealed to minimize any losses of TCE due to volatilization. However, in order to determine further losses, blank samples (i.e., unexposed control samples) were analyzed routinely. Then, the real concentration of each sample was calculated by subtracting the blank values from the results of the exposed samples. The oxygen gas entrance valve (marked $d$ in Figure 1) was then opened until the pressure gauge displayed the desired pressure. Adjustment of the pressure was done manually by opening and closing the gas pressure regulating valve ( $c$ in Figure 1) and the gas entrance valve. To provide continuous agitation, the reactor was placed on a shaker.

\section{Analysis}

The TCE concentrations were measured using a Varian CP-3800 (Australia) gas chromatograph (GC), equipped with an FID and a $30 \mathrm{~m} \times 0.32 \mathrm{~mm} \mathrm{CP}-$ Sil \& CB capillary column with a film thickness of $0.25 \mu \mathrm{m}$. The initial oven temperature of $35^{\circ} \mathrm{C}$ was increased at a rate of $16^{\circ} \mathrm{C} / \mathrm{min}$ to a final temperature of $100^{\circ} \mathrm{C}$. The injector temperature was $150^{\circ} \mathrm{C}$. The inlet was operated in $20 \%$ split mode. Helium (99.999\%) was used as the carrier gas at a rate of $1 \mathrm{~mL} / \mathrm{min}$.

\section{Results and discussion}

\section{Effect of $\mathrm{H}_{2} \mathrm{O}_{2}$ concentration}

Aqueous solutions with different initial concentrations of TCE and different concentrations of $\mathrm{H}_{2} \mathrm{O}_{2}(10,25,50$ and $100 \mathrm{mg} / \mathrm{L}$ ) at neutral $\mathrm{pH}$, and $\mathrm{TiO}_{2}$ concentration of $50 \mathrm{mg} / \mathrm{L}$ were exposed to UPDO $(1 \mathrm{~atm})$ for $45 \mathrm{~min}$. The removal rate of TCE versus $\mathrm{H}_{2} \mathrm{O}_{2}$ concentration is shown in Figure 2. As an overall trend it is clear that the percentage of degradation for all TCE concentrations increased quite rapidly with the increase in $\mathrm{H}_{2} \mathrm{O}_{2}$ concentration until $50 \mathrm{mg} / \mathrm{L}$ and that at concentrations

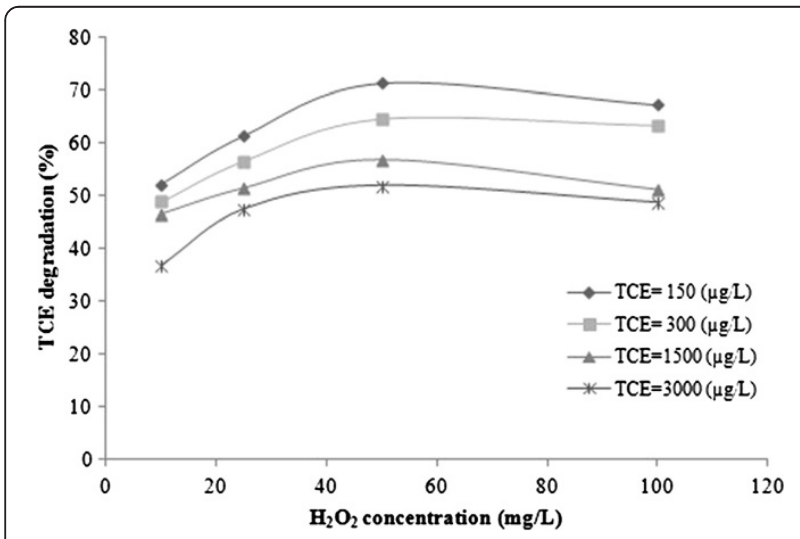

Figure $2 \mathrm{TCE}$ removal at different $\mathrm{H}_{2} \mathrm{O}_{2}$ concentrations; $\mathrm{TiO}_{2}$ concentration $=50 \mathrm{mg} / \mathrm{L}$, oxygen pressure $=1 \mathrm{~atm}, \mathrm{pH}=$ neutral and time $=45 \mathrm{~min}$. higher than this the TCE removal rate decreased. Apparently, the quenching of $\mathrm{OH}^{*}$ radicals according to the below quenching reactions causes the reduction in TCE degradation at $\mathrm{H}_{2} \mathrm{O}_{2}$ concentrations above $50 \mathrm{mg} / \mathrm{L}$. Quenching reactions may include [9]:

$$
\begin{aligned}
& \mathrm{OH}^{\bullet}+\mathrm{H}_{2} \mathrm{o}_{2} \rightarrow \mathrm{HO}_{2} \cdot+\mathrm{H}_{2} \mathrm{O} \\
& \mathrm{OH}^{\bullet}+\mathrm{HO}_{2} \cdot \rightarrow \mathrm{O}_{2}+\mathrm{H}_{2} \mathrm{O}
\end{aligned}
$$

It appears that in the advanced oxidation processes based on hydrogen peroxide, the effectiveness of $\mathrm{H}_{2} \mathrm{O}_{2}$ on the degradation of TCE depends on the type of process and the other available oxidants that may be used as synergists; for example Jung et al. found that in the radiation treatment of TCE and tetrachloroethylene (PCE) by gamma-rays, the presence of $\mathrm{H}_{2} \mathrm{O}_{2}$ did not affect the decomposition process [11]. However, it is reported that degradation of TCE by sonication in the presence of $\mathrm{H}_{2} \mathrm{O}_{2}$ is dependent upon the $\mathrm{H}_{2} \mathrm{O}_{2}$ concentration. The best TCE degradation rate was achieved at an $\mathrm{H}_{2} \mathrm{O}_{2}$ concentration of $10 \mathrm{mg} / \mathrm{L}$ and increasing the $\mathrm{H}_{2} \mathrm{O}_{2}$ concentration from 10 to $50 \mathrm{mg} / \mathrm{L}$ did not affect the TCE destruction [10]. Therefore, there is a maximum level of $\mathrm{H}_{2} \mathrm{O}_{2}$ beyond which any improvement in the degradation rate is decreased; and in our experiments the maximum level was $50 \mathrm{mg} / \mathrm{L}$.

\section{Effect of $\mathrm{TiO}_{2}$ concentration}

Figure 3 shows the removal of TCE at different concentrations of $\mathrm{TiO}_{2}(25,50,100$ and $200 \mathrm{mg} / \mathrm{L})$ at neutral $\mathrm{pH}, 50 \mathrm{mg} / \mathrm{L} \mathrm{H}_{2} \mathrm{O}_{2}, 1 \mathrm{~atm}$ of oxygen and a reaction time of $45 \mathrm{~min}$. As shown in this figure, the TCE removal increased with an increase in $\mathrm{TiO}_{2}$ concentration and reached a plateau at a $\mathrm{TiO}_{2}$ concentration of $100 \mathrm{mg} / \mathrm{L}$, after which it remained approximately stable. This result is similar to the results reported by other researchers who studied the effect of $\mathrm{TiO}_{2}$ nano-particles on the degradation of other organic pollutants in various AOPs

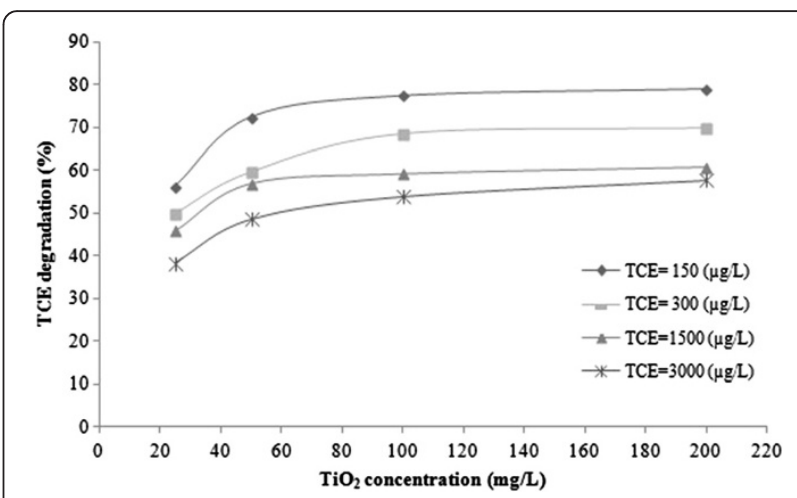

Figure 3 Degradation of TCE at different $\mathrm{TiO}_{2}$ concentrations. $\mathrm{H}_{2} \mathrm{O}_{2}$ concentration $=50 \mathrm{mg} / \mathrm{L}$, oxygen pressure $=1 \mathrm{~atm}, \mathrm{pH}=$ neutral and time $=45 \mathrm{~min}$. 


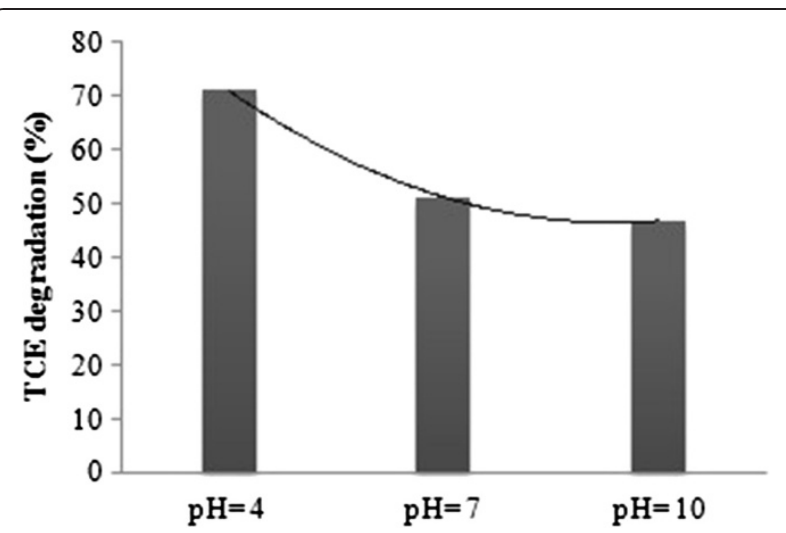

Figure 4 Effect of $\mathrm{pH}$ on TCE degradation. TCE $=1500 \mu \mathrm{g} / \mathrm{L}$, $\mathrm{TiO}_{2}=100 \mathrm{mg} / \mathrm{L}, \mathrm{H}_{2} \mathrm{O}_{2}=50 \mathrm{mg} / \mathrm{L}$, oxygen pressure $=1 \mathrm{~atm}$, and time $=45 \mathrm{~min}$.

$[10,14,15]$. Yamazaki et al. compared the effectiveness of Degussa P-25 $\mathrm{TiO}_{2}$ nano-particles with the commercially available PC-101 and PC-102 powders in addition to SG powders, which are prepared by the sol-gel method of photocatalytic degradation of TCE in water. They found that the degradation rate of TCE using P-25 was about three-fold higher than when the same experiments were performed with the other three aforementioned nanoparticle powders. Differences in the degradation rates were mainly due to different specific surface area, crystal structure, and specific volume of the various $\mathrm{TiO}_{2}$ powders [2]. Some studies have determined that in the AOPs which use $\mathrm{TiO}_{2}$ nano-particles as catalysts for the removal of organic pollutants, when the concentration of nano-particles exceeds a certain value, the activated $\mathrm{TiO}_{2}$ may deactivate through collisions with groundstate catalysts. Additionally, agglomeration and sedimentation of $\mathrm{TiO}_{2}$ occurs in the presence of high concentrations of catalyst [16-18]. Therefore, lack of any increase in TCE removal efficiency at $\mathrm{TiO}_{2}$ concentrations higher than $100 \mathrm{mg} / \mathrm{L}$ in our work can be attributed to deactivation, agglomeration and sedimentation of $\mathrm{TiO}_{2}$ nano-particles. Avoiding these problems is essential to the optimization of $\mathrm{TiO}_{2}$ concentration.

\section{Effect of $\mathrm{pH}$}

In AOPs, $\mathrm{pH}$ can influence the pollutant degradation rate. As shown in Figure 4, there was a significant difference in TCE degradation at various $\mathrm{pHs}$; and the degradation was significantly higher in acidic $\mathrm{pH}$. Similar results were obtained by Teel et al. who found that TCE degradation in goethite-catalyzed reactions increased significantly with decreasing $\mathrm{pH}$. They also reported that the degradation rate of pentachlorophenol in Fenton's reactions decreased significantly with increasing $\mathrm{pH}[9]$. Although acidic conditions appear to enhance catalysis by $\mathrm{TiO}_{2}$ in the reactor, the underlying mechanism for this effect is unknown. In addition, under some conditions $\mathrm{H}_{2} \mathrm{O}_{2}$ based reactions are highly redox sensitive, and $\mathrm{OH}^{\cdot}$ formation due to $\mathrm{H}_{2} \mathrm{O}_{2}$ decomposition increases significantly under the reducing conditions of low $\mathrm{pH}$.

Table 1 Fitted equations and $\mathrm{R}^{2}$ related to percent TCE degradation versus reaction time for different oxygen pressures under optimized conditions

\begin{tabular}{|c|c|c|c|}
\hline Oxygen $\left(\mathrm{O}_{2}\right)$ pressure (atm) & $\mathrm{TCE}(\mu \mathrm{g} / \mathrm{L})$ & Fitted equation & $\mathrm{R}^{2}$ \\
\hline \multirow{4}{*}{1} & 150 & $y=4 E-05 x^{3}-0.014 x^{2}+1.641 x+23.40$ & 0.999 \\
\hline & 300 & $y=4 E-05 x^{3}-0.014 x^{2}+1.735 x+16.82$ & 0.995 \\
\hline & 1500 & $y=5 E-05 x^{3}-0.015 x^{2}+1.680 x+14.22$ & 0.997 \\
\hline & 3000 & $y=5 E-05 x^{3}-0.015 x^{2}+1.675 x+10.45$ & 0.995 \\
\hline \multirow{4}{*}{1.5} & 150 & $y=6 E-05 x^{3}-0.018 x^{2}+1.894 x+25.84$ & 0.998 \\
\hline & 300 & $y=5 E-05 x^{3}-0.014 x^{2}+1.630 x+24.96$ & 0.996 \\
\hline & 1500 & $y=2 E-05 x^{3}-0.009 x^{2}+1.310 x+23.36$ & 0.999 \\
\hline & 3000 & $y=2 E-05 x^{3}-0.010 x^{2}+1.455 x+13.85$ & 0.999 \\
\hline \multirow{4}{*}{2} & 150 & $y=3 E-05 x^{3}-0.010 x^{2}+1.307 x+41.45$ & 0.996 \\
\hline & 300 & $y=3 E-05 x^{3}-0.011 x^{2}+1.476 x+32.36$ & 0.996 \\
\hline & 1500 & $y=4 E-05 x^{3}-0.014 x^{2}+1.651 x+24.65$ & 0.995 \\
\hline & 3000 & $y=4 E-05 x^{3}-0.012 x^{2}+1.442 x+24.79$ & 0.999 \\
\hline \multirow{4}{*}{2.5} & 150 & $y=3 E-05 x^{3}-0.010 x^{2}+1.307 x+41.45$ & 0.996 \\
\hline & 300 & $y=3 E-05 x^{3}-0.011 x^{2}+1.476 x+32.36$ & 0.996 \\
\hline & 1500 & $y=4 E-05 x^{3}-0.014 x^{2}+1.651 x+24.65$ & 0.995 \\
\hline & 3000 & $y=4 E-05 x^{3}-0.012 x^{2}+1.442 x+24.79$ & 0.999 \\
\hline
\end{tabular}




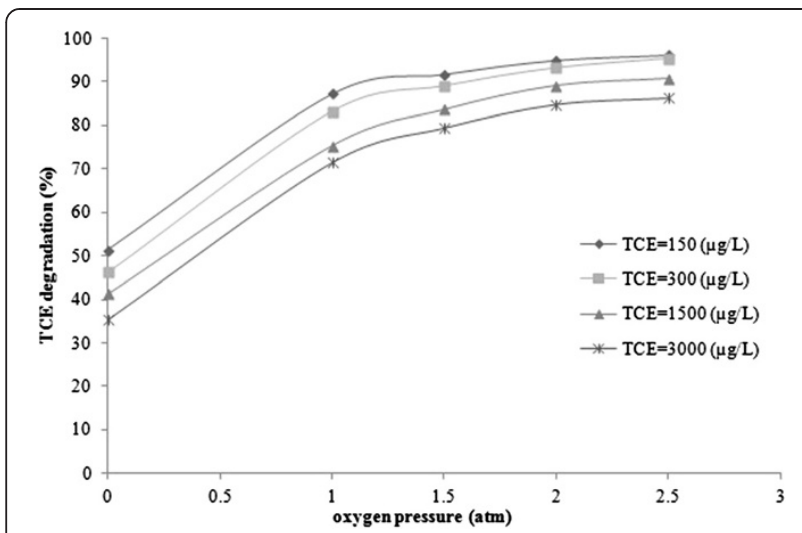

Figure 5 Degradation of TCE in various oxygen pressures $\left(\mathrm{H}_{2} \mathrm{O}_{2}=50 \mathrm{mg} / \mathrm{L}, \mathrm{TiO}_{2}=100 \mathrm{mg} / \mathrm{L}, \mathrm{pH}=4\right.$ and reaction time $90 \mathrm{~min}$ ).

\section{Effect of reaction time and initial TCE concentration}

To investigate the effect of reaction time and initial TCE concentration on the TCE removal rate, given concentrations of TCE were exposed to four different oxygen pressures during six reaction times with the optimized values of $\mathrm{H}_{2} \mathrm{O}_{2}$ concentration $(50 \mathrm{mg} / \mathrm{L}), \mathrm{TiO}_{2}$ loading $(100 \mathrm{mg} / \mathrm{L})$ and $\mathrm{pH}$ value (4). Table 1 shows the fitted equations and $R^{2}$ value relative to percent TCE degradation versus reaction time for different oxygen pressures. As shown in this table the best fit trend lines for percent degradation versus reaction time were polynomial. The results showed that the degradation percent increased with increasing reaction time from 15 to $90 \mathrm{~min}$ and then stayed approximately constant. Decreasing the initial concentration of TCE caused an increase in removal rate. For example, at an oxygen pressure of $1 \mathrm{~atm}$, initial TCE concentration of $150 \mu \mathrm{g} / \mathrm{L}$, and contact time of 90 minutes, $87.21 \%( \pm 6.82 \%)$ TCE degradation was achieved; whereas for concentrations of 300 , 1500 and $3000 \mu \mathrm{g} / \mathrm{L}$, the average ( \pm S.D.) of TCE removal efficiency were $83.13 \%( \pm 7.23 \%), 75.28 \%( \pm$ $5.65 \%)$ and $71.46 \%( \pm 5.65 \%)$ respectively. This trend was also observed at other oxygen pressures. This may be explained by the fact that under the same conditions, the $\mathrm{OH}^{\circ}$ radical densities were equal in all solutions; therefore, the reaction of TCE with $\mathrm{OH}^{\circ}$ radicals becomes more likely at lower TCE concentrations, resulting in an overall increase in TCE degradation by $\mathrm{OH}^{\circ}$ radicals [10]. This result was in agreement with results reported by other researchers who studied TCE degradation by various AOPs. For example, Huang et al. studied the potential of gamma radiation technology for TCE degradation and found that with increasing initial concentration of TCE, increased time and gamma-ray dosage was required for the degradation process [19].

\section{Effect of under pressure oxygen}

Figure 5 shows the TCE removal percentage versus oxygen pressure for various initial concentrations of TCE following a $90 \mathrm{~min}$ reaction time with optimized values of $\mathrm{H}_{2} \mathrm{O}_{2}, \mathrm{TiO}_{2}$ and $\mathrm{pH}$; and Figure 6 shows the additional removal of TCE due to the application of 2 atm of oxygen under optimum conditions. According to Figure 5, TCE degradation increased rapidly with increasing oxygen pressure. It can be clearly seen that without applying oxygen, the overall degradation of TCE is low. Without oxygen pressure the percentages of TCE degradation were $48.27 \%, 51.22 \%, 58.13 \%$ and $64.33 \%$ for TCE concentrations of 3000, 1500, 300 and $150 \mu \mathrm{g} / \mathrm{L}$, respectively. These degradation percentages increased markedly to $71.46 \%, 75.28 \%, 83.13 \%$ and $87.21 \%$ at $1 \mathrm{~atm}$ of oxygen. These values gradually continued to increase up to an oxygen pressure of $2 \mathrm{~atm}$. At this pressure the degradation rates were $84.85 \%, 89.14 \%, 93.13 \%$, and $94.99 \%$ for TCE concentrations of 3000, 1500, 300 and $150 \mu \mathrm{g} / \mathrm{L}$ respectively. Accordingly, the degradation rate at this pressure was enhanced by approximately

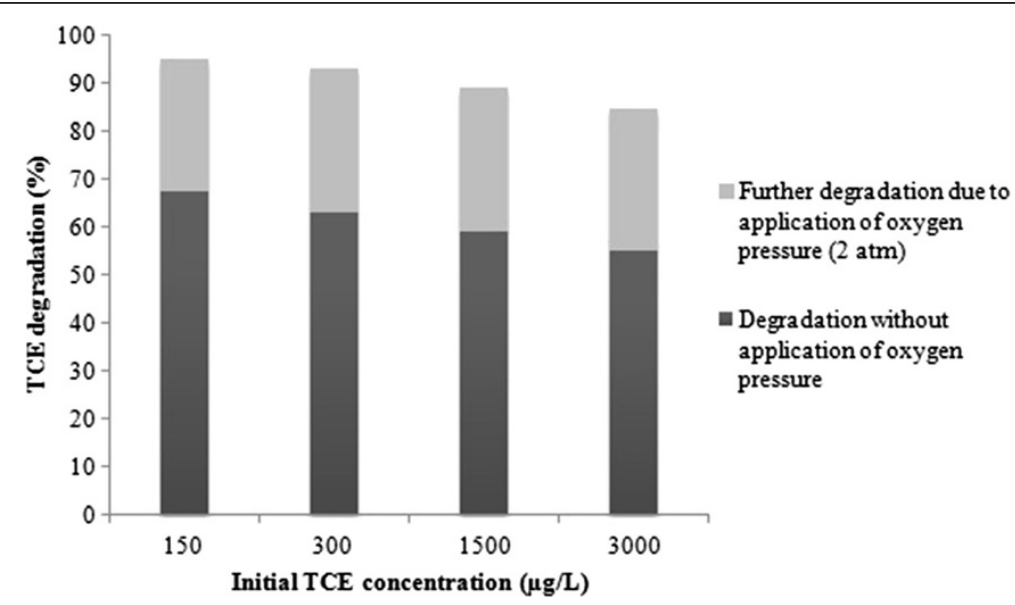

Figure 6 Additional removal of TCE due to the application of an oxygen pressure of 2 atm under optimum conditions. 
$30 \%$ compared to those conditions in which oxygen was not applied. As illustrated, the TCE removal rate did not change significantly above oxygen pressures of 2 atm. Isaev et al. have studied the influence of dissolved oxygen under pressure on electrochemical oxidation of toluene and acetone from aqueous solutions. They reported that the oxidation of toluene and acetone by electrolysis under oxygen pressure was accelerated due to the generation of active particles of the ions $\mathrm{O}_{2}^{-}$and $\mathrm{HO}_{2}^{-}$, and radicals including $\mathrm{HO}_{2}{ }^{\circ}$ and $\mathrm{HO}^{\circ}$. They also showed that increasing the oxygen pressure increased the efficiency of the overall process [20].

The increasing TCE degradation with increasing oxygen pressure in our present work can be attributed to the generation of $\mathrm{OH}^{\circ}$ radicals due to the reaction between $\mathrm{H}_{2} \mathrm{O}_{2}$ and pressurized $\mathrm{O}_{2}$, similar to the reaction which occurs between $\mathrm{H}_{2} \mathrm{O}_{2}$ and $\mathrm{O}_{3}$ for the production of hydroxyl radicals as follows [21]:

$$
\mathrm{H}_{2} \mathrm{O}_{2}+2 \mathrm{O}_{3} \rightarrow \mathrm{OH}^{\circ}+\mathrm{OH}^{\circ}+3 \mathrm{O}_{2}
$$

Therefore, the efficiency of hydroxyl radical production plays an important role in the degradation of TCE and PCE.

\section{Conclusions}

In this study degradation of TCE was investigate in a stainless steel reactor with various experimental conditions including different $\mathrm{H}_{2} \mathrm{O}_{2}$ concentrations, $\mathrm{TiO}_{2}$ nano-particle dosage, $\mathrm{pH}$, initial TCE concentration and different oxygen pressure. The results of this study show that the optimum conditions for TCE degradation are an $\mathrm{H}_{2} \mathrm{O}_{2}$ concentration of $50 \mathrm{mg} / \mathrm{L}$, a $\mathrm{TiO}_{2}$ concentration of $100 \mathrm{mg} / \mathrm{L}$, an acidic $\mathrm{pH}$ and a reaction time of $90 \mathrm{~min}$. Additionally, the results indicated that under pressure dissolved oxygen has a synergistic effect on the $\mathrm{H}_{2} \mathrm{O}_{2}$ / $\mathrm{TiO}_{2}$ AOP and enhances the degradation of TCE. The application of $2 \mathrm{~atm}$ of dissolved oxygen under optimized conditions improved the effectiveness of TCE degradation by $30 \%$. This synergistic effect provides a promising technology for the removal of TCE and can also be used to remove other organic contaminants from aqueous solutions.

\section{Competing interests}

The authors declare that they have no competing interests.

\section{Authors' contributions}

The overall implementation of this study including design, experiments and data an analysis, and manuscript preparation were the results of efforts by corresponding author. All authors have made extensive contribution into the review and finalization of this manuscript. All authors read and approved the final manuscript.

\section{Acknowledgments}

The authors are grateful to all laboratory staff of the Department of Environmental Health Engineering, Tehran University of Medical Sciences for their support throughout this study.
Received: 3 March 2013 Accepted: 25 September 2013

Published: 20 December 2013

\section{References}

1. US.EPA: Trichloroethylene. Technology Transfer Network, air Toxics web Site. 2007. in: www.epa.gov/ttn/atw/hlthef/tri-ethy.html\#ref4.

2. Yamazaki S, Matsunaga S, Hori K: Photocatalytic degradation of trichloroethylene in water using $\mathrm{TiO}_{2}$ pellets. Water Res 2001, 35:1022-1028.

3. McGregor DB, Heseltine E, ller H MÃ: Dry cleaning, some solvents used in dry cleaning and other industrial chemicals. IARC meeting, Lyon, 7-14 February 1995. Scand J Work Environ Health 1995, 21:310-312.

4. ATSDR: Toxicological Profile for Trichloroethylene. U.S. Public Health Service, U.S. Department of Health and Human Services. Atlanta, GA; 1997. On line at: http://www.atsdr.cdc.gov/toxprofiles/tp19.pdf.

5. US.EPA: Trichloroethylene Hazard Summary. 2000.

6. Wartenberg D, Reyner D, Scott CS: Trichloroethylene and cancer: epidemiologic evidence. Environ Health Perspect 2000, 108:161-176.

7. US.EPA: EPA Ground Water Issu. In TCE Removal from Contaminated Soil and Ground Water, Office of Solid Waste and Emergency Response, EPA1540/S92/002. Edited by Russell HH, Matthews JE, Sewell GW. 1992.

8. Nakano Y, Hua LQ, Nishijima W, Shoto E, Okada M: Biodegradation of trichloroethylene (TCE) adsorbed on granular activated carbon (GAC). Water Res 2000, 34:4139-4142.

9. Teel AL, Warberg CR, Atkinson DA, Watts RJ: Comparison of mineral and soluble iron Fenton's catalysts for the treatment of trichloroethylene. Water Res 2001, 35:977-984.

10. Dobaradaran S, Nabizadeh R, Mahvi AH, Mesdaghinia AR, Yunesian M, Rastkari N, Nazmara S: Survey on degradation rates of trichloroethylene in aqueous solutions by ultrasound. Iran J Environ Health Sci Eng 2010, 7:307-312.

11. Jung J, Yoon JH, Chung HH, Lee MJ: Comparative study of $\mathrm{H}_{2} \mathrm{O} 2$ and $\mathrm{O} 3$ effects on radiation treatment of TCE and PCE. Chemosphere 2003, 51:881-885.

12. Cross JB, Currier RP, Torraco DJ, Vanderberg LA, Wagner GL, Gladen PD: Killing of Bacillus spores by aqueous dissolved oxygen, ascorbic acid, and copper ions. Appl Environ Microbiol 2003, 69:2245-2252.

13. Dobaradaran S, Nabizadeh R, Mahvi AH, Noroozi A, Yunesian M, Rastkari N, Nazmara S, Zarei S: Kinetic and degradation efficiency of trichloroethylene (TCE) via photochemical process from contaminated water. Afr J Biotechnol 2012, 11:2006-2012.

14. Ghanbarian M, Nabizadeh R, Mahvi AH, Nasseri S, Naddafi K: Photocatalytic degradation of linear alkyl benzene solfunate from aqueous solution by $\mathrm{TiO}_{2}$ nanoparticles. Iran J Environ Health Sci Eng 2011, 8:309-316.

15. Mahvi AH, Ghanbarian M, Nasseri S, Khairi A: Mineralization and discoloration of textile wastewater by $\mathrm{TiO} 2$ nanoparticles. Desalination 2009, 239:309-316.

16. Neppolian B, Choi HC, Sakthivel S, Arabindoo B, Murugesan V: Solar/UVinduced photocatalytic degradation of three commercial textile dyes. J Hazard Mater 2002, 89:303-317.

17. San N, Murat K, Tuiebakhova Z, Cinar Z: Enhancement and modeling of the photocatalytic degradation of benzoic acid. J Adv Oxid Technol 2007, 10:43-50.

18. So CM, Cheng MY, Yu JC, Wong PK: Degradation of azo dye Procion Red MX-5B by photocatalytic oxidation. Chemosphere 2002, 46:905-912.

19. Huang SK, Hsieh LL, Chen CC, Lee PH, Hsieh BT: A study on radiation technological degradation of organic chloride wastewater-Exemplified by TCE and PCE. Appl Radiat Isot 2009, 67:1493-1498.

20. Isaev AB, Aliev ZM, Alieva DS: Influence of the dissolved oxygen under pressure to electrochemical oxidation toluene and acetone aqueous mixtures. Electrochem Commun 2007, 9:1400-1403.

21. Munter R: Advanced oxidation processes: current status and prospects. Proc Estonian Acad Sci Chem 2001, 50:59-80.

\section{doi:10.1186/2052-336X-11-38}

Cite this article as: Hoseini et al: Influence of under pressure dissolved oxygen on trichloroethylene degradation by the $\mathrm{H}_{2} \mathrm{O}_{2} / \mathrm{TiO}_{2}$ process. Journal of Environmental Health Sciences \& Engineering 2013 11:38. 